\title{
Change detection and visualization of acid mine lakes using time series satellite image data in geographic information systems (GIS): Can (Canakkale) County, NW Turkey
}

\author{
Deniz Sanliyuksel Yucel • Mehmet Ali Yucel • \\ Alper Baba
}

Received: 8 March 2013/Accepted: 29 April 2014/Published online: 20 May 2014

(C) Springer-Verlag Berlin Heidelberg 2014

\begin{abstract}
Can, a county in the province of Canakkale, is one of the most prominent coal mining districts in Turkey. Many mining companies have been operating coal deposits for power generation and district heating in this region since 1980. Generally, small and medium-scale mining companies operate for short periods and abandon the operational land without providing any rehabilitation. Human intervention in the natural structure and topography of the earth surface causes large holes and deterioration in these areas. Artificial lakes occur because of surface discharge and underground leakage into abandoned open pit mines with high lignite sulfur content (0.21-14.36 wt \%). Furthermore, these lakes gain acidic character due to acid generation from pyrite oxidation. Acid mine lakes are highly acidic $(\mathrm{pH}<3.05)$ and have elevated concentrations of $\mathrm{SO}_{4}^{2-}, \mathrm{Fe}$ and some metals. The main objective of this study is to evaluate the environmental conditions and demonstrate the development of a monitoring system for their possible changes in the acid mine lakes of the open cast lignite mining area on a regional scale. For this purpose, the data received from remote sensing satellites were used. Areal change detection and perimeter changes of nine acid mine lakes caused by coal mining companies in Can
\end{abstract}

D. S. Yucel

Department of Geology Engineering, Canakkale Onsekiz Mart University, Canakkale, Turkey

M. A. Yucel $(\bowtie)$

Department of Geomatics Engineering, Canakkale Onsekiz Mart University, Canakkale, Turkey

e-mail: aliyucel@comu.edu.tr

A. Baba

Department of Civil Engineering, Izmir Institute of Technology, Izmir, Turkey from 1977 to 2011, were determined using Landsat, Quickbird and Worldview satellite images. As a case study, an area of $9 \mathrm{~km}^{2}$ was chosen for the variety of acid mine lakes. Using GIS software, satellite images were analyzed in time series, borders of acid mine lakes were digitized and converted into vector data format. At this stage, prior to the digitization, in order to create contrast on the satellite images, "stretch type" and "stretch values" were changed. The areal and perimeter changes were computed and presented via tables and graphics. In addition, thematic maps of the acid mine lakes were created and visualized. The results show that the number of acid mine lakes increased and these caused environmental risks due to their hydrochemical properties and areal increments.

Keywords Acid mine lake $\cdot$ Change detection $\cdot$ Coal mining · GIS · Satellite image data

\section{Introduction}

Mining activities cause environmental damage and changes to the earth's surface and underground. Abandoned mines contaminate drainage water, soil, air and ecologic variety (Bell et al. 2001; Bhattacharya et al. 2006; Ribeiro et al. 2010; Si et al. 2010). Pollution of drainage water is continuously generated and dispersed into the area downstream of the mine (Oh and Lee 2011). Acid mine drainage (AMD) is generally defined as the product formed by the atmospheric oxidation (i.e., by water, oxygen and carbon dioxide) of the relatively common iron-sulfur minerals such as pyrite $\left(\mathrm{FeS}_{2}\right)$ and pyrrhotite $(\mathrm{FeS})$ in the catalyzing presence of Acidithiobacillus ferrooxidans, an acidophilic bacterium, and any other products generated as a consequence of these oxidation reactions (USEPA 1994a, b; Mills 1995; Akcil and Koldas 
2006; Ozcelik 2007; Sanliyuksel Yucel and Baba 2013a). Nearly all metallic and most coal mines contain pyrite or other sulfides that oxidize when exposed to the surface environment, generating sulfuric acid (Nordstrom 1982). Acid mine lakes (AML) are a world-wide problem because of the acid mine drainage system. It is vitally important to evaluate surface water quality and environmental damage through acid mine drainage using remote sensing methods (Paktunc 1999; Sabins 1999; Schroeter and Glasser 2011).

A multidisciplinary approach to reduce ecological and economic problems is required for all mining consequences within active and abandoned mines (Schroeter and Glasser 2011). A systematic and multidisciplinary approach to mapping, monitoring and controlling the impact caused by mining activities is necessary to understand the character of hazardous events in an area (Woldai 2001). Information about the temporal and spatial data of different parameters (geological, hydrochemical etc.) is essential in each phase of mining for the success of both the productivity and for reclamation of the land.

Satellite data have been successfully used to monitor the effects of AMD in mining areas such as coal mining and in areas with abundant mining waste (Spahn 1983; Paterson 1997) and to locate abandoned mine sites in northern Ontario in Canada with contaminant AMD problems (Robitaille et al. 1991; Paterson 1997). Peichang et al. (2004) used GIS and remote sensing to identify acid mine lakes in an Ohio coal mining area. Latifovic et al. $(2005,2006)$ investigated changes in forest areas due to mining activities near Fort McMurray in Canada. Yenilmez et al. (2011) investigated pollution levels at an abandoned coal mine site in Cankiri (north-central Turkey) which were evaluated with respect to topography and surface runoff pathways derived using GIS tools. Oh and Lee (2011) used GIS to generate ground subsidence hazard maps of abandoned coal mines in Samcheok, Korea. Schroeter and Glasser (2011) studied physicochemical properties of post mining lakes demonstrating the use of multitemporal analysis Landsat TM5/ETM +7 satellite data as basis for a monitoring system for geochemistry of mining lakes.

\section{Study area}

The study area is geographically situated approximately $17 \mathrm{~km}$ southwest of the county of Can, which is located in Canakkale province of northwestern Turkey (Fig. 1). This region is associated with intense mining activities because of its geological and tectonic properties. Therefore, open/underground mining operations for coal production and industrial raw materials are present. Also, this region and its vicinity have important water resources.

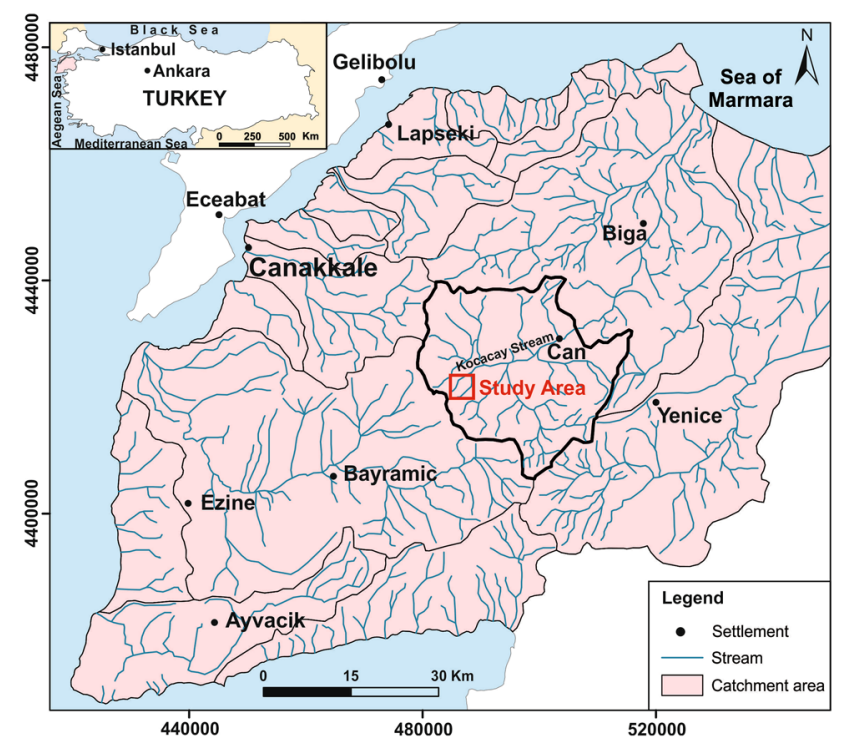

Fig. 1 Location map of study area

Canakkale province is situated in a climatic transition between Mediterranean and Black Sea climate zones. The summers are hot and dry, and the winters are relatively wetter and colder. The long term (1970-2011) mean annual temperature was $15.2{ }^{\circ} \mathrm{C}$ with a minimum of $-11.2{ }^{\circ} \mathrm{C}$ (February, 2004) and a maximum of $39^{\circ} \mathrm{C}$ (July, 2007) based on data collected at Canakkale Meteorological Station located about $40 \mathrm{~km}$ northwest of the study area. Precipitation in the region is mostly in the form of rain and the highest precipitation is observed in winter. The mean annual precipitation rate was $594.6 \mathrm{~mm}$ between the years 1970 and 2011.

The majority of creeks originating from the study area are drained into Kocacay Stream which is the second largest stream in Canakkale province and it flows northeast through the counties of Can and Biga and eventually drains into the Sea of Marmara approximately $45-50 \mathrm{~km}$ north of Can. The hydrology of the surface drainage network in Kocacay demonstrates a variable flow regime, which mainly depends on the seasonal precipitation pattern. Based on long-term monthly averages, the mean annual flow rate of Kocacay Stream is found to be $1.28 \mathrm{~m}^{3} / \mathrm{s}$ at gaging station (Baba et al. 2009). The highest flows are observed during spring months where snowmelt is augmented by spring rains.

Many mining companies have been operating coal deposits for power generation and district heating in the Can region since 1980. Generally, small and medium-scale mining companies operate for short periods and abandon the operational land without providing any rehabilitation. As a result of human intervention in the natural structure and topography of the earth surface, large holes and deterioration form in these areas. Artificial lakes occur due to both surface discharge and underground leakage into abandoned open pit mines and they are characterized by 
Table 1 Coordinates and elevations of acid mine lakes (UTMWGS84)

\begin{tabular}{llll}
\hline Lake & Easting $(\mathrm{m})$ & Northing $(\mathrm{m})$ & $H(\mathrm{~m})$ \\
\hline AML 1 & 488,957 & $4,421,785$ & 245 \\
AML 2 & 487,988 & $4,423,658$ & 172 \\
AML 3 & 487,315 & $4,423,813$ & 151 \\
AML 4 & 488,390 & $4,424,103$ & 140 \\
AML 5 & 488,399 & $4,424,305$ & 128 \\
AML 6 & 487,220 & $4,422,413$ & 223 \\
AML 7 & 488,901 & $4,423,935$ & 149 \\
AML 8 & 489,035 & $4,422,178$ & 226 \\
AML 9 & 488,737 & $4,421,964$ & 230 \\
\hline
\end{tabular}

specific limnological development changes. High sulfur content lignite exists in these areas. Furthermore, these lakes gain acidic character due to acid generation from pyrite oxidation. AMLs are more dangerous than AMD as a result of the massive volume of water that potentially poses a threat to the environment. This study focuses on nine acid mine lakes (AML 1, 2, 3, 4, 5, 6, 7, 8 and 9) (Table 1; Figs. 2,3) which are topographically situated within range of 128-245 m elevation above mean sea level. The acid mine lakes drainage adits from both sides discharge acid mine drainage into the Kocacay Stream. The weathering product of sulfide oxidation is the formation of iron hydroxide, a red/orange-colored precipitate found in dozens of miles of streams affected by AMD (Sanliyuksel Yucel et al. 2013).

\section{Geological and hydrogeological setting}

The study area mainly consists of acidic and agglomeratic tuff, andesite, trachyandesite and andesitic tuff which are called the Can volcanics (Ercan et al. 1995). The volcanic successions of Can volcanic rocks are enriched with high sulfur content, due to alteration processes and structural controls. Widespread and intense zones of silicified, argillic and propylitic alteration can be observed in the Can volcanics (Sanliyuksel Yucel et al. 2012). In the EarlyMiddle Miocene; terrestrial units were deposited with the calc-alkaline volcanic activity (Siyako et al. 1989). These terrestrial units consist of bituminous shale, siltstone, claystone, sandstone, tuff, and coals, named the Can formation, which is up to $250 \mathrm{~m}$ thick and unconformably overlies the Miocene-aged andesitic volcanic rocks (Siyako et al. 1989) (Fig. 4). The Can formation is rich in lignite (also known as brown coal) and $17 \mathrm{~m}$ thick (Bozcu et al. 2008). The sulfur content of lignite varies between 0.21 and 14.36 wt \% (Gurdal 2011).

The hydrogeology of the study area is primarily dominated by volcanic units. Silicified zones of these volcanics are typically situated as a cap over the volcanic rocks. The silicified volcanics in the study demonstrate fractured aquifer characteristics. Dense argillic alteration, demonstrating impervious properties due to its high clay content, can also be seen below the silicified alteration zone. These clayish zones act as a barrier beneath the fractured aquifer. In general, most of the springs in the study area surface out from the boundary between fractured aquifer (silicified zone) and impervious boundary (argillic zone). The flow rates of these springs range between 0.01 and $3 \mathrm{~L} / \mathrm{s}$ (Baba and Gunduz 2010). Also, many drills were done in volcanic units in the study area. Flow rates of these drills ranged from 0.2 to $0.7 \mathrm{~L} / \mathrm{s}$ in volcanics. Hydraulic conductivity values of volcanics units ranged from $1 \times 10^{-7}$ to $1 \times 10^{-8} \mathrm{~m} / \mathrm{sn}$ (SRK 2012). According to these data, volcanics can be described as less-permeable and impermeable aquifers. Generally clay alteration of volcanics has
Fig. 2 Drainage system of study area

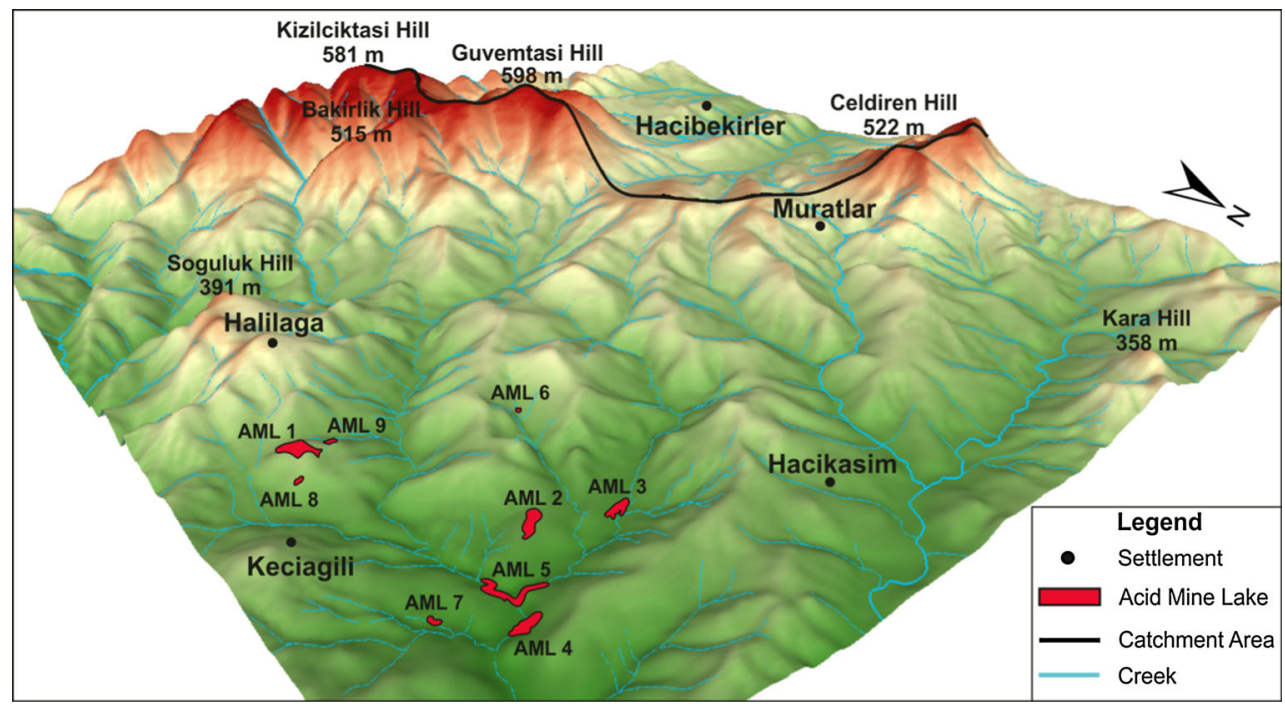


Fig. 3 Snapshots from AMLs a AML 1, b AML 2, c AML 3, d AML 4, e AML 5, f AML 6, g AML 7, h AML 8, i AML 9
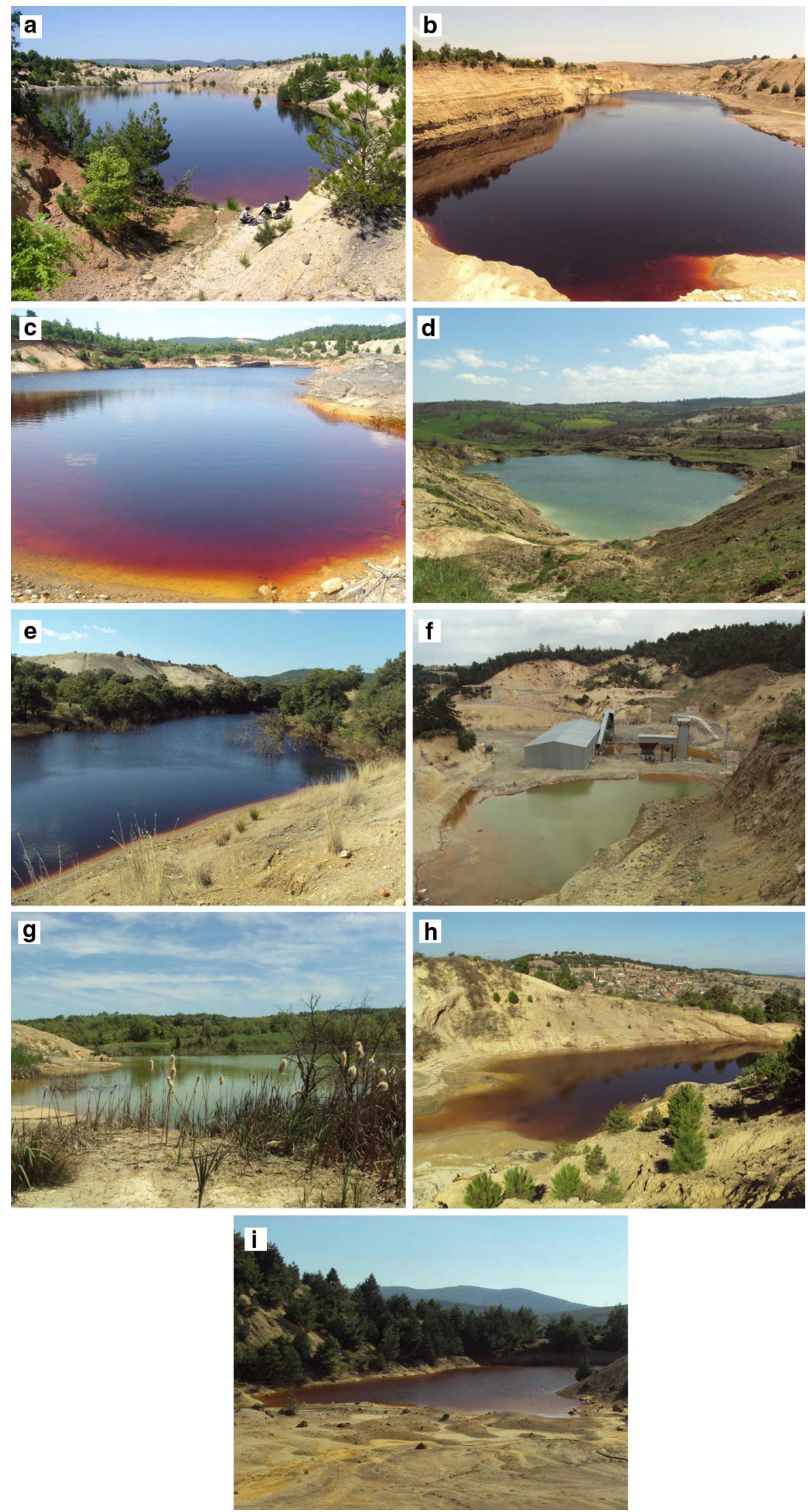


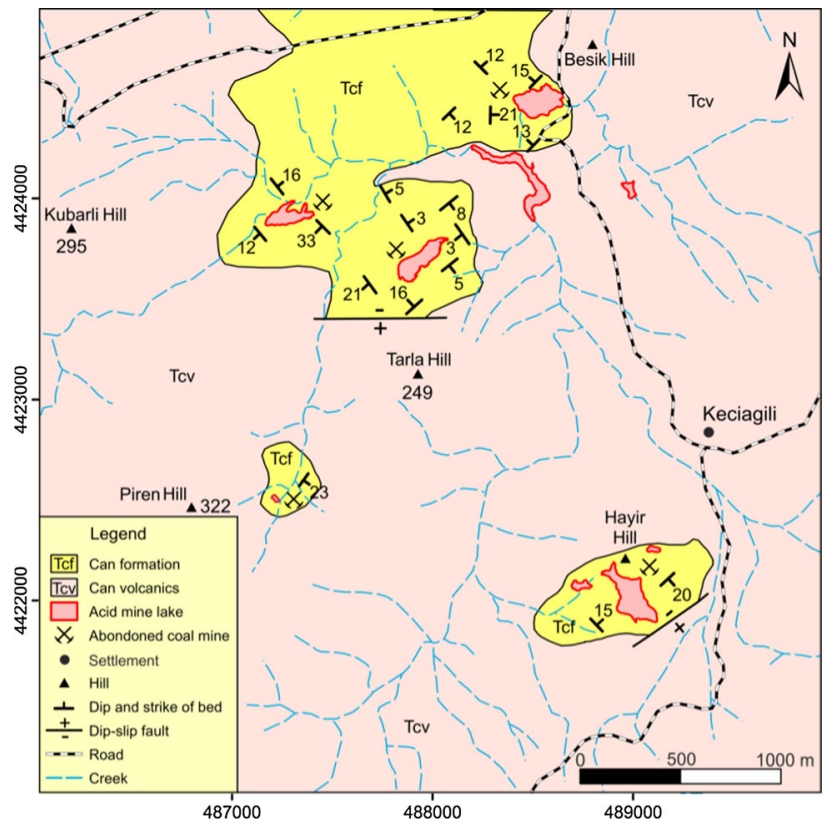

Fig. 4 Geological map of study area (Sanliyuksel Yucel and Baba 2013a) and location of AMLs

a high storage capability, but this part of volcanic unit is not a good aquifer. In addition, Can formation has a less permeable unit in study area. Flow rates of springs in Can formation range from 0.01 to $0.5 \mathrm{~L} / \mathrm{s}$ in study area. The depths of drillings in Can formation are range from 100 to $150 \mathrm{~m}$ depth. The flow rates of these drills are range between 1 and $1.5 \mathrm{~L} / \mathrm{s}$ (Baba et al. 2009). Groundwater flow direction is SW to NE and water table is generally followed by topography. Groundwater level changes average of $2 \mathrm{~m}$ between in dry and wet period.

\section{Methods}

\section{Satellite data}

Satellite image data are relatively inexpensive and have large coverage and an increased volume of information. Moreover, they are multi-temporal and available on a large scale (Anderson et al. 2004; Ozesmi and Bauer 2002; Schroeter and Glasser 2011). This study is based on time series data sets from Landsat, Landsat 5, Landsat 7, Quickbird and Worldview (USGS 2006a, b, c) satellites. This investigation uses cloud-free images between May and November of the years 1977, 1985, 1987 and 1999 from Landsat data and between March and July of the years 2003, 2008 and 2011 from Quickbird and Worldview. The Landsat TM (Thematic Mapper) and Landsat ETM+ (Enhanced Thematic Mapper Plus) data have a geometric resolution of 30 per $30 \mathrm{~m}$ and per pixel. The Landsat MSS

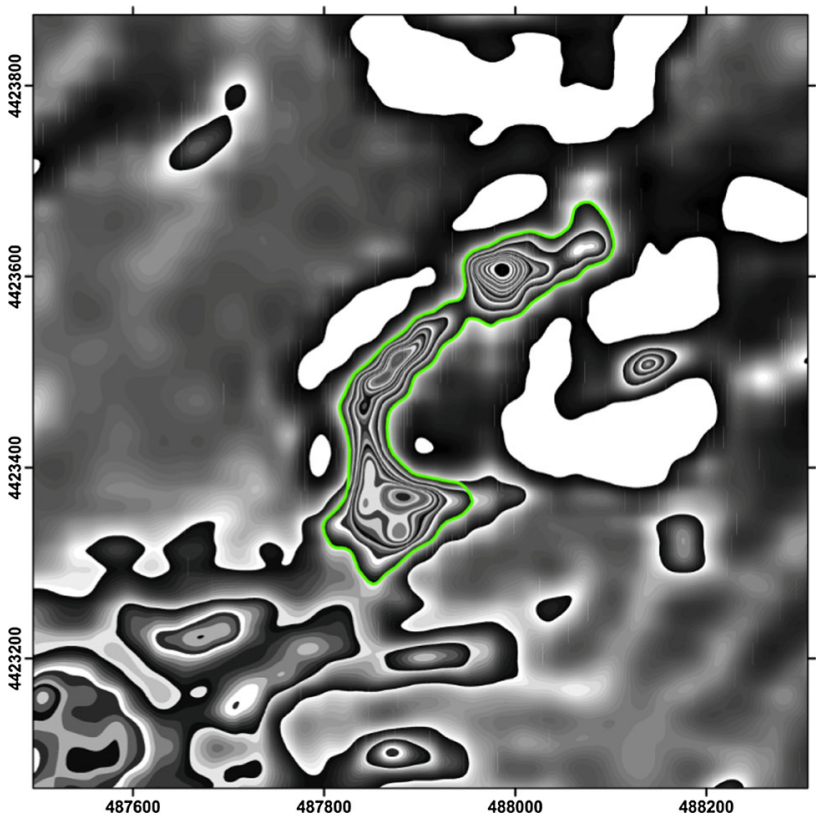

Fig. 5 Digitizing of Landsat satellite image (1999, AML 2)

(Multispectral Scanner) data have a geometric resolution of 60 per $60 \mathrm{~m}$ and per pixel. Quickbird data have a geometric resolution of 60 per $60 \mathrm{~cm}$ and per pixel. Worldview data have a geometric resolution of 50 per $50 \mathrm{~cm}$ and per pixel. Landsat MSS, Landsat TM and Landsat ETM +, Quickbird and Worldview ground resolution of multispectral bands is suitable for scaled images up to a maximum of about 1:50.000 for 1:25.000 and 1:5000. In 2009, the Landsat archive images became freely available to research users. Landsat images were downloaded from USGS website; Quickbird and Worldview images were purchased from NIK System Inc. Co. Remote Sensing Department.

\section{Change detection and visualization}

In this study, the satellite images were adjusted geometrically with the software ENVI 5.0 in order to transform them into precisely scaled images for GIS implementation. Then they were transformed to UTM coordinates (WGS84UTM Zone $35 \mathrm{~N}$ ). By this process, all data and layers were overlaid precisely.

The satellite images were imported into ArcGIS 9.3 software and acid mine lake borders were digitized manually. This process was generated for Quickbird and Worldview images directly, which have high resolution data. Landsat satellite images were of lower resolution; therefore the "stretch type" adjustment of these images was changed to "standard deviations" and gamma "stretch values" were entered as " -1 ". This process generated sharpened images. The acid mine lake borders were easily and accurately determined. After this adjustment process 

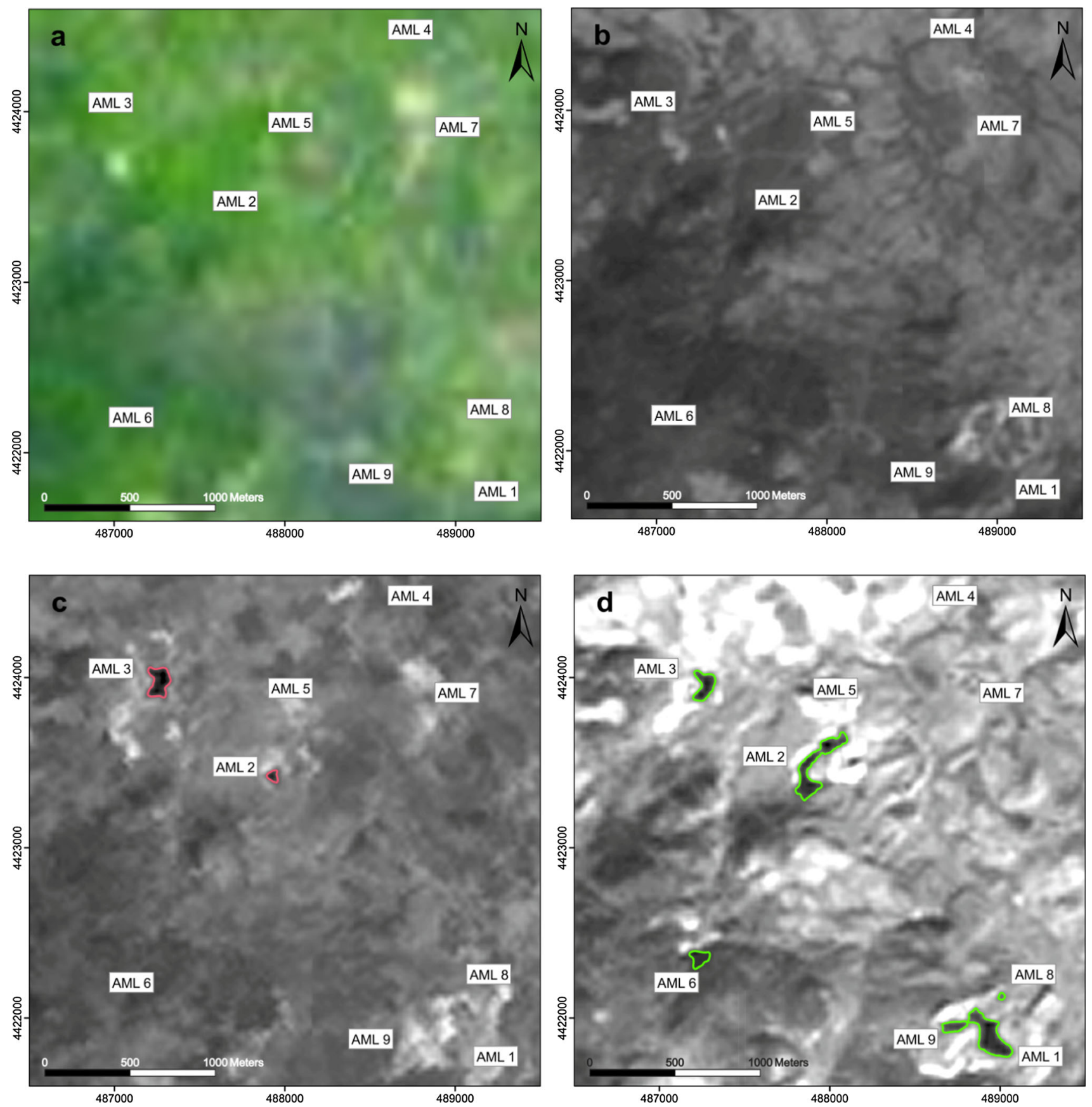

Fig. 6 Change detection of AMLs in time period a 1977, b 1985, c 1987, d 1999, e 2003, f 2008, g 2011

acid mine lakes on Landsat satellite images were digitized (Fig. 5). Border change detection of acid mine lakes was provided by the digitizing process.

Using ArcGIS 9.3 software, satellite images were analyzed in time series, borders of acid mine lakes were digitized and converted into vector data format. The areal and perimeter changes were computed and presented via tables and graphics. Thereby, thematic maps of the acid mine lakes were created and visualized using cartographic rules.
Water chemistry

Nine acid mine lakes, where water samples were taken, were monitored in August 2012 in the study area. Water samples were transferred to polyethylene bottles of 500 and $50 \mathrm{~mL}$ capacity and kept in portable coolers. The $500 \mathrm{~mL}$ samples were used in anion and cation analysis and the $50 \mathrm{~mL}$ samples were used for some elements. Physical and chemical analysis of water included primary field 

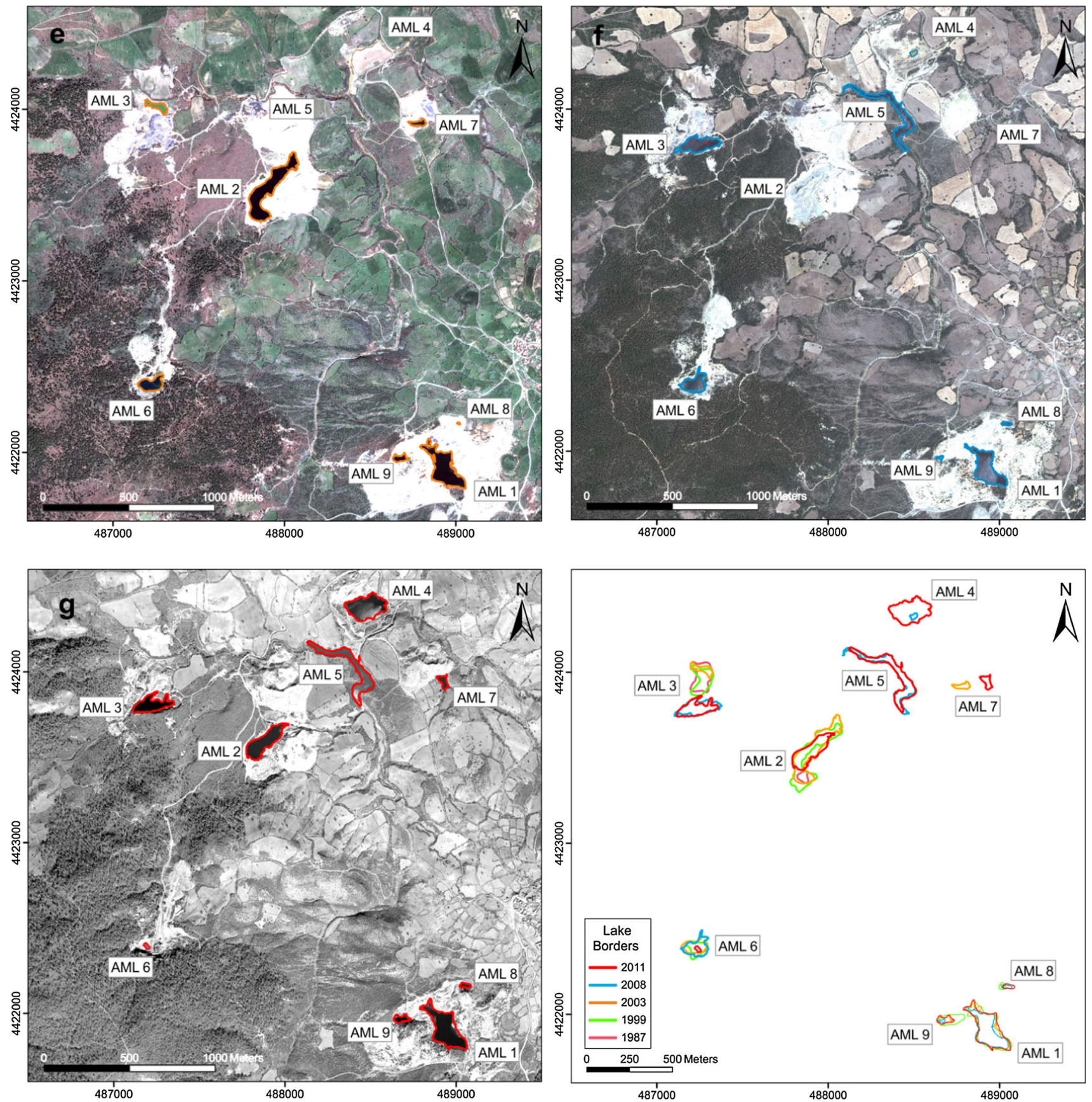

Fig. 6 continued

parameters $(\mathrm{pH}$, redox potential, temperature, salinity and electrical conductivity), major anions and cations (sodium, potassium, calcium, magnesium, chloride and sulfate) and elements (aluminum, iron, manganese and sulfur). All water samples were filtered through $0.45 \mu \mathrm{m}$ filter paper and stored in polyethylene bottles at $4{ }^{\circ} \mathrm{C}$. The physical field parameters were instantly measured in situ at water points with a multi-parameter probe WTW model 340i. The major cations and elements were analyzed with inductively coupled plasma mass spectrometry (ICP-MS), $\mathrm{SO}_{4}$ and $\mathrm{Cl}$ was analyzed by ion chromatography (IC) at Acme Analytical Laboratories in Canada.

Morphological properties of AML 2 were studied in July 2010. The bathymetry of the lake was measured using a $30 \mathrm{~m}$ marine rope marked at $1 \mathrm{~m}$ intervals that was tied to $1 \mathrm{~kg}$ weight. Lake depth was measured at $15 \mathrm{~m}$ intervals along a $235 \mathrm{~m}$ long transect $\left(\mathrm{A}-\mathrm{A}^{\prime}\right)$ across the longest part of the lake for a total of 15 depth measurements. 
Table 2 Perimeter values of acid mine lakes

\begin{tabular}{|c|c|c|c|c|c|c|c|c|c|c|}
\hline \multirow[t]{2}{*}{ Satellite } & \multirow[t]{2}{*}{ Date } & \multicolumn{9}{|c|}{ Perimeters of acid mine lakes (m) } \\
\hline & & AML 1 & AML 2 & AML 3 & AML 4 & AML 5 & AML 6 & AML 7 & AML 8 & AML 9 \\
\hline Landsat MSS & 21.05 .1977 & - & - & - & - & - & - & - & - & - \\
\hline Landsat $5 \mathrm{TM}$ & 26.09 .1985 & - & - & - & - & - & - & - & - & - \\
\hline Landsat 5 TM & 11.05 .1987 & - & 222 & 581 & - & - & - & - & - & - \\
\hline Landsat 7 ETM+ & 28.11 .1999 & 908 & 1,257 & 552 & - & - & 372 & - & 124 & 367 \\
\hline Quickbird & 30.04 .2003 & 1,235 & 1,329 & 385 & - & - & 451 & 254 & 51 & 276 \\
\hline Quickbird & 21.07.2008 & 971 & - & 699 & 129 & 1,671 & 585 & - & 142 & 111 \\
\hline Worldview-1 & 15.03 .2011 & 1,026 & 851 & 811 & 736 & 1,465 & 105 & 271 & 165 & 269 \\
\hline
\end{tabular}

Table 3 Areal change of acid mine lakes

\begin{tabular}{|c|c|c|c|c|c|c|c|c|c|c|c|}
\hline \multirow[t]{2}{*}{ Satellite } & \multirow[t]{2}{*}{ Date } & \multirow[t]{2}{*}{ Resolution } & \multicolumn{9}{|c|}{ Areas of acid mine lakes (ha) } \\
\hline & & & AML 1 & AML 2 & AML 3 & AML 4 & AML 5 & AML 6 & AML 7 & AML 8 & AML 9 \\
\hline Landsat MSS & 21.05.1977 & $60 \mathrm{~m} \times 60 \mathrm{~m}$ & - & - & - & - & - & - & - & - & - \\
\hline Landsat $5 \mathrm{TM}$ & 26.09 .1985 & $30 \mathrm{~m} \times 30 \mathrm{~m}$ & - & - & - & - & - & - & - & - & - \\
\hline Landsat 5 TM & 11.05 .1987 & $30 \mathrm{~m} \times 30 \mathrm{~m}$ & - & 0.3200 & 1.6426 & - & - & - & - & - & - \\
\hline Landsat 7 ETM+ & 28.11 .1999 & $30 \mathrm{~m} \times 30 \mathrm{~m}$ & 3.2381 & 3.1518 & 1.3530 & - & - & 0.7931 & - & 0.1156 & 0.7182 \\
\hline Quickbird & 30.04 .2003 & $60 \mathrm{~cm} \times 60 \mathrm{~cm}$ & 2.9697 & 3.3466 & 0.4235 & - & - & 0.9166 & 0.2490 & 0.0164 & 0.2817 \\
\hline Quickbird & 21.07.2008 & $60 \mathrm{~cm} \times 60 \mathrm{~cm}$ & 2.3383 & - & 1.5437 & 0.1049 & 2.1304 & 1.1329 & - & 0.0966 & 0.0524 \\
\hline Worldview-1 & 15.03 .2011 & $50 \mathrm{~cm} \times 50 \mathrm{~cm}$ & 3.1654 & 2.0768 & 1.4407 & 2.5543 & 2.3830 & 0.0611 & 0.2912 & 0.1441 & 0.3114 \\
\hline
\end{tabular}

Fig. 7 Time versus perimeter change of AMLs $\square \mathrm{AML} 1 \square \mathrm{AML} 2 \square \mathrm{AML} 3 \square \mathrm{AML} 4 \square \mathrm{AML} 5 \square \mathrm{AML} 6 \square \mathrm{AML} 7 \square \mathrm{AML} 8 \square \mathrm{AML} 9$

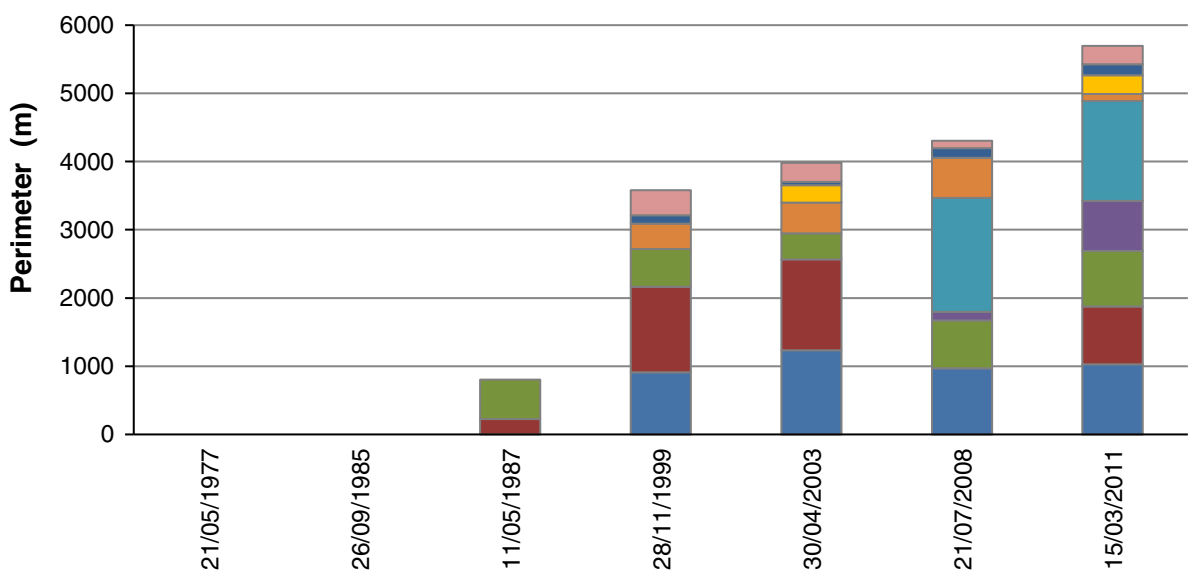

\section{Results and discussion}

Areal and perimeter changes of acid mine lakes

Acid mine lakes 2 and 3 are the oldest lakes, followed by AML 1, AML 6, AML 8, AML 9, AML 7 and finally AML 5 and 4 (Fig. 6). AML 5 is situated on the old stream bed, and formed as a result of prevention of water flow by huge amounts of mine waste (Yucel and Sanliyuksel Yucel
2012). AML 5 had a maximum perimeter value of $1,671 \mathrm{~m}$, in 2008 (Table 2). AML 2 had a maximum surface area in 2003, of 3.34 ha (Table 3). Areal change of acid mine lakes effects from environmental conditions such as annual precipitation, evaporation and drainage patterns (Yucel et al. 2013). Total perimeter and area of all acid mine lakes reached maximum levels of $5,699 \mathrm{~m}$ and $12.42 \mathrm{ha}$, respectively, in 2011 (Figs. 7, 8). Around the AMLs, the effluent drains into nearby rivers and into water sources 
Fig. 8 Time versus areal change of acid mine lakes $\square \mathrm{AML} 1 \square \mathrm{AML} 2 \square \mathrm{AML} 3 \square \mathrm{AML} 4 \square \mathrm{AML} 5 \square \mathrm{AML} 6 \square \mathrm{AML} 7 \square \mathrm{AML} 8 \square \mathrm{AML} 9$

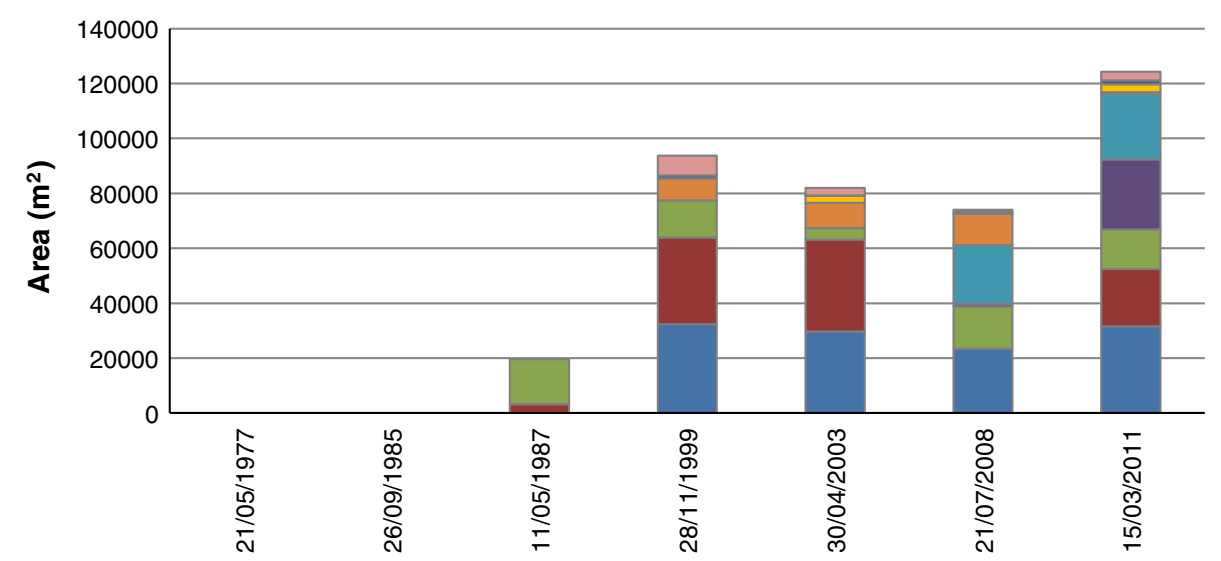

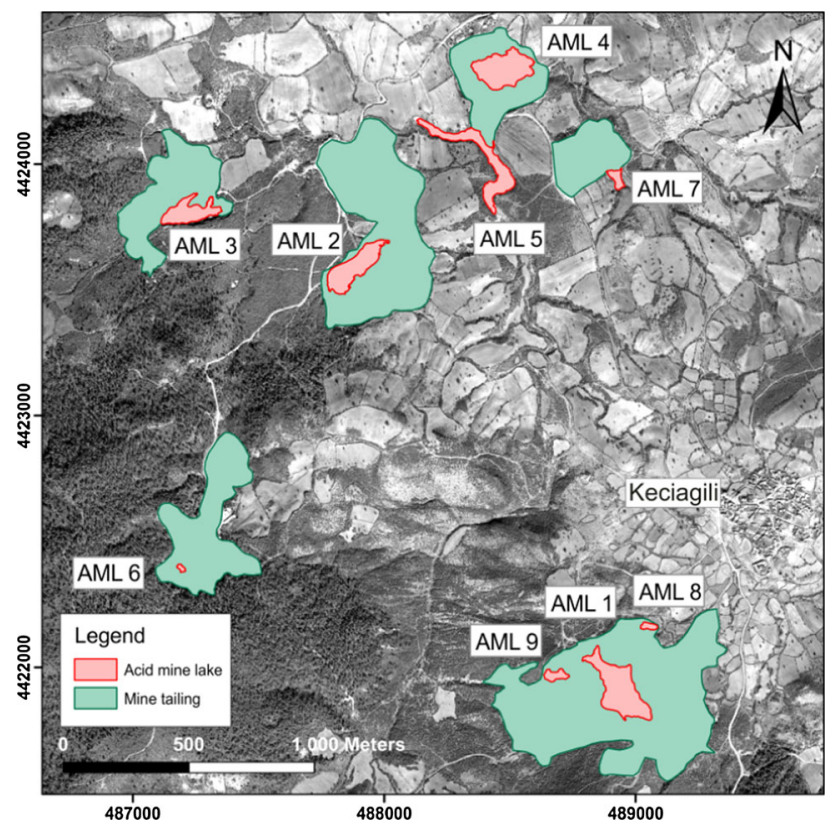

Fig. 9 Area of mine tailings around acid mine lakes

from the mine tailings which had a total area of 166.26 ha, in the year 2011 (Fig. 9). Total area of acid mine lakes and mine tailings were 178 ha in 2011; they covered 20 per cent of the study area.

The deepest point in AML 2 was $13.45 \mathrm{~m}$ deep and the average depth of the lake was $7.41 \mathrm{~m}$ (Fig. 10). The perimeter and surface area of the lake were $616 \mathrm{~m}$ and $15.55 \mathrm{~m}^{2}$, respectively in 2010 (Sanliyuksel Yucel and Baba 2013a).

Open pit coal mine tailings continue to generate acidity and acidify surface water. Lakes and streams affected by coal mines have limited aquatic life due to low $\mathrm{pH}$ and high metal concentrations in water. AMLs are very close to Keciagili Village and all lakes around the village are affected by AMD. AML 2 was discharged into Kocacay
Stream in 2008 because of mining activities and resulted in serious environmental problems. It is also worthwhile to mention that in Can basin, fish deaths due to the seepage and discharge of the acid mine lakes into surface waters have been observed (Sanliyuksel and Baba 2011). It is clear that acid mine lakes cause environmental risks due to their presence and areal increments.

Hydrogeochemistry of acid mine lakes

Acidification due to pyrite oxidation is a major problem for water quality in acid mine lakes. The field parameter results of AML measurements are presented in Table 4. These results indicate that the $\mathrm{pH}$ of AMLs range from 2.53 to 3.05 (Fig. 11a). The $\mathrm{pH}$ of a solution is an important measure for evaluating aquatic toxicity (Cravotta 2008). The electrical conductivity (EC) values of AMLs ranged between 2,890 and $6,750 \mu \mathrm{s} / \mathrm{cm}$ (Fig. 11b). The electrical conductivity indicates the relatively high concentrations of dissolved solids in AMLs, mainly sulfate in the case of acid lakes $\mathrm{pH}<3$, and iron. The Eh values range between 208 and $240 \mathrm{mV}$. High acidity and high redox potential values are mainly due to the presence of significant quantities of dissolved $\mathrm{Fe}^{3+}$ which acts as a more effective oxidizing agent than $\mathrm{O}_{2}$, in the most acidic environments (Monterroso and Macias 1998). AMLs have different colors, AML 4 is blue, AML 7 is green and others are orange-red-brown in color. Precipitates associated with AMD can be characterized by particular colors depending on their composition (Bigham et al. 1994; Nordstrom et al. 2000). $\mathrm{Fe}^{3+}$ precipitates give the iron hydroxide the colors of yellow, red, orange and brown during the formation reactions of AMD. Jarosite was identified by XRD results in bottom sediment in AMLs (Sanliyuksel Yucel and Baba 2013b). Jarosite is a straw yellow mineral that is common in the weathered zone of sulfide ore deposits and in acid sulfate soils. These minerals also gives color of AMLs. 


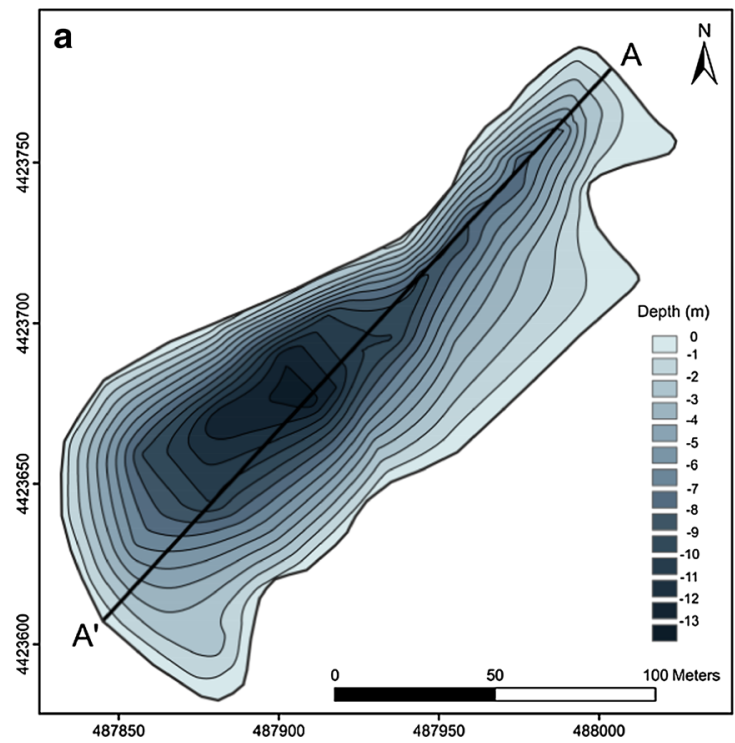

b

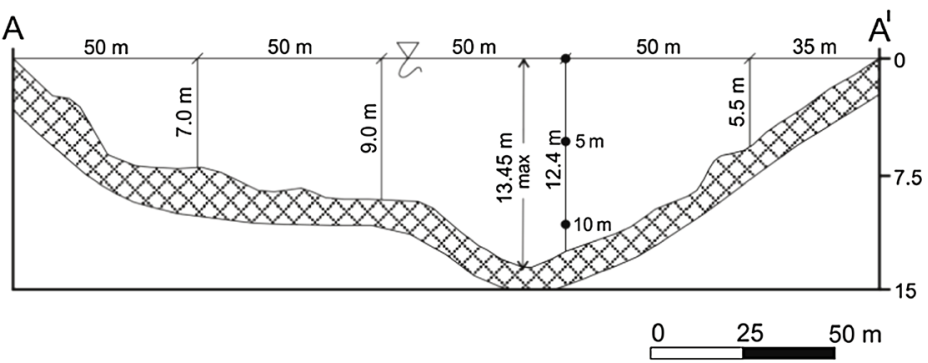

Fig. 10 a Bathymetry of AML 2 (July, 2010), b The vertical profile on A-A ${ }^{1}$ cross-section (Sanliyuksel Yucel and Baba 2013a)

Table 4 Physical parameters, major ion and some element values of acid mine lakes (mg/L) (August, 2012)

\begin{tabular}{|c|c|c|c|c|c|c|c|c|c|}
\hline Lake Name & AML 1 & AML 2 & AML 3 & AML 4 & AML 5 & AML 6 & AML 7 & AML 8 & AML 9 \\
\hline $\mathrm{pH}$ & 2.56 & 2.53 & 2.57 & 3.05 & 2.65 & 2.79 & 2.87 & 2.71 & 2.79 \\
\hline $\mathrm{Eh}(\mathrm{mV})$ & 236 & 238 & 235 & 208 & 233 & 231 & 219 & 242 & 240 \\
\hline $\mathrm{T}\left(\right.$ Lake, $\left.{ }^{\circ} \mathrm{C}\right)$ & 25.4 & 25.3 & 25.3 & 27.7 & 27.6 & 27.4 & 26.7 & 27 & 27.2 \\
\hline $\mathrm{T}\left(\right.$ Air, $\left.{ }^{\circ} \mathrm{C}\right)$ & 21.9 & 22.3 & 23.2 & 24.3 & 24.8 & 25.6 & 25.4 & 25.2 & 24.9 \\
\hline $\mathrm{EC}(\mu \mathrm{S} / \mathrm{cm})$ & 5,070 & 6,750 & 4,070 & 3,550 & 3,520 & 3,980 & 2,890 & 5,780 & 5,910 \\
\hline Sal (\%o) & 2.7 & 3.7 & 2.1 & 1.8 & 1.8 & 2.1 & 1.4 & 2.9 & 3.2 \\
\hline Color & \multicolumn{3}{|c|}{ Orange-red-brown } & Blue & \multicolumn{2}{|c|}{ Orange-red-brown } & Green & \multicolumn{2}{|c|}{ Orange-red-brown } \\
\hline $\mathrm{Na}^{+}$ & 110.6 & 170.2 & 99.8 & 270.6 & 86.9 & 167.5 & 190.6 & 106.7 & 105.8 \\
\hline $\mathrm{K}^{+}$ & 1.8 & 2 & 4.9 & 16.2 & 12.9 & 3.1 & 11.8 & 1.7 & 1.65 \\
\hline $\mathrm{Ca}^{2+}$ & 490.2 & 525.3 & 241 & 463.2 & 179.8 & 357.5 & 428.6 & 430.7 & 445.6 \\
\hline $\mathrm{Mg}^{2+}$ & 226 & 353 & 89.4 & 115.7 & 64.9 & 289.4 & 137.8 & 229.7 & 216.3 \\
\hline $\mathrm{SO}_{4}^{2-}$ & 3,240 & 4,600 & 1,650 & 1,760 & 1,055 & 3,690 & 1,750 & 3,210 & 3,140 \\
\hline $\mathrm{Cl}^{-}$ & 70.5 & 150 & 70.6 & 105 & 74 & 124 & 102 & 80.9 & 82.5 \\
\hline $\mathrm{Al}$ & 283.31 & 357.47 & 131.53 & 17.18 & 63.18 & 159.68 & 27.01 & 287.11 & 285.21 \\
\hline $\mathrm{Fe}$ & 92.8 & 338.17 & 35.16 & 7.23 & 24.98 & 131.77 & 7.19 & 92.01 & 91.96 \\
\hline $\mathrm{Mn}$ & 83.84 & 164.97 & 28.17 & 32.43 & 20.17 & 101.07 & 33.14 & 84.16 & 84.39 \\
\hline S & 1,356 & 1,892 & 679 & 616.7 & 389 & 1,282 & 620.3 & 1,317 & 1,301 \\
\hline
\end{tabular}

Hydrogeochemical processes play a major role in determining the quality of water draining from the waste rock pile. The wide variety of minerals in waste and host rocks influences the resultant drainage composition. Sulfate is clearly the dominating anion in all AMLs. It results mainly from pyrite oxidation. Sulfate levels were observed to range between 1,055 and $4,600 \mathrm{mg} / \mathrm{L}$ with a mean value of $2,677.22 \mathrm{mg} / \mathrm{L}$, which exceeds the water quality standard of $250 \mathrm{mg} / \mathrm{L}$ by a factor of 10 (Environmental Protection Agency 2003; WHO 2004; ITASHY 2005)
(Table 4). Magnesium and calcium values ranged between 64.9 and $353 \mathrm{mg} / \mathrm{L}$, and between 179 and $525.3 \mathrm{mg} / \mathrm{L}$, respectively.

The geochemical behaviors of $\mathrm{Fe}$ and $\mathrm{Al}$ mainly control the mobility of metals though adsorption and coprecipitation in the acidic sulfate water (Bigham and Nordstrom 2000; Lee et al. 2002; Lee and Chon 2006; Equeenuddin et al. 2010). Various kinds of ochers, mainly iron oxyhydroxide sulfates, precipitate along the AMD impacted river (Bigham and Nordstrom 2000; Equeenuddin et al. 2010). 

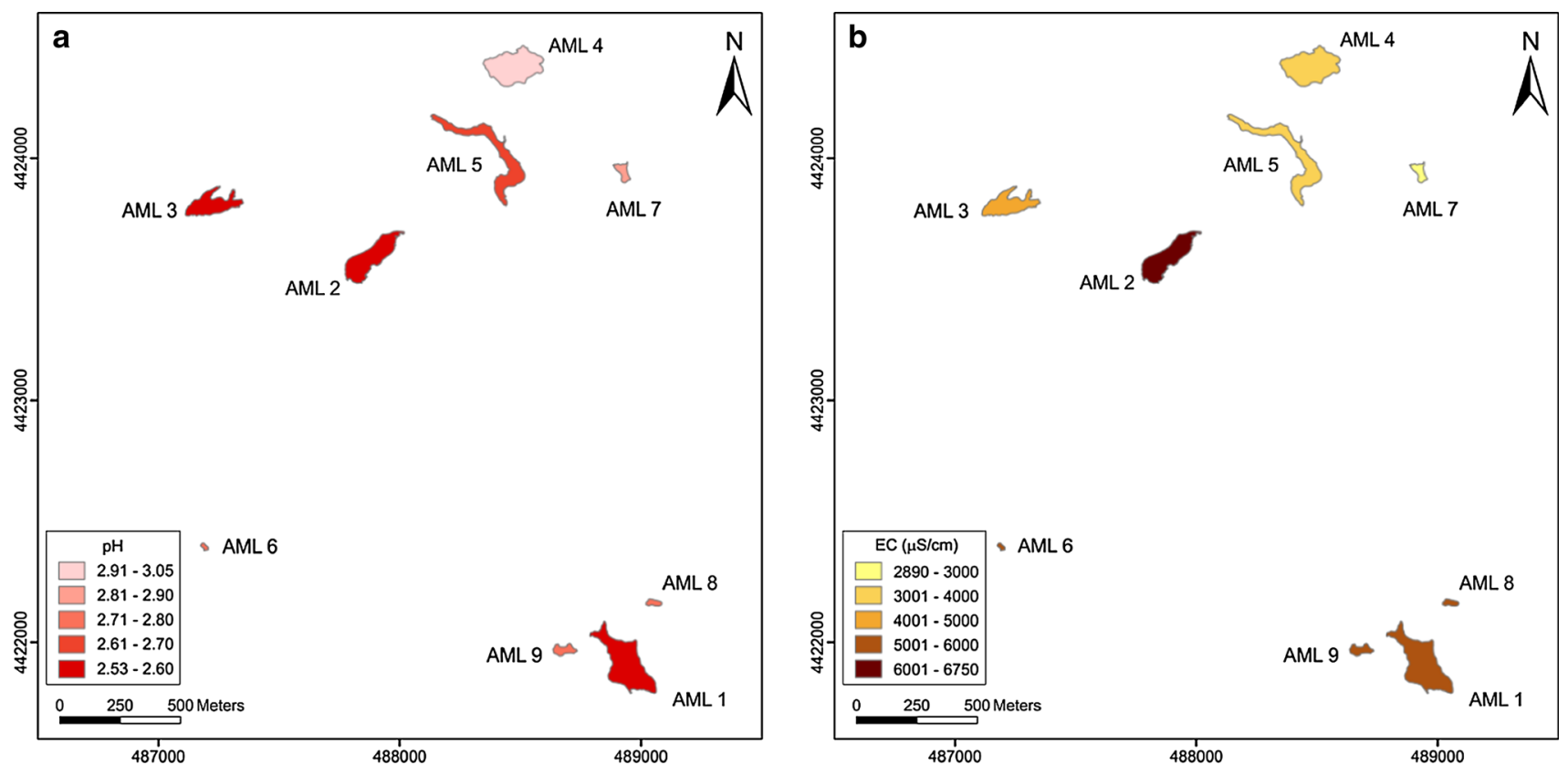

Fig. 11 a pH, b electrical conductivity values of acid mine lakes (August, 2012)

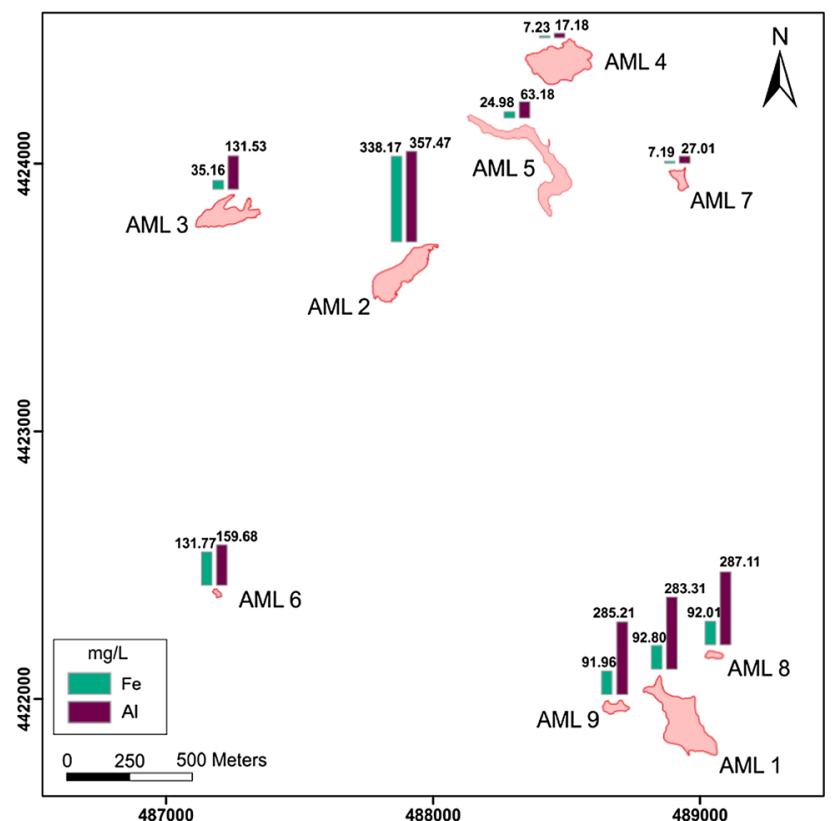

Fig. 12 Iron and aluminum concentrations of AMLs (August, 2012)

Iron and aluminum are the most predominant metal species in the AMLs in the study area. It was observed that iron concentrations ranged between 7.19 and $338.17 \mathrm{mg} / \mathrm{L}$ (Table 4). The concentration of aluminum was observed to range between 17.18 and $357.47 \mathrm{mg} / \mathrm{L}$ (Fig. 12). The high aluminum concentrations are also a clue for the high clay content of the regional rocks. High concentration of $\mathrm{Al}$ and $\mathrm{Fe}$ result in important increases in acidity and provokes the buffering of the AMD systems. These lakes also have extremely high concentrations of manganese that were observed to range between 20.17 and $164.97 \mathrm{mg} / \mathrm{L}$. High sulfur concentrations were found in all lakes, the maximum level was as high as $1,892 \mathrm{mg} / \mathrm{L}$. It was expected that the sulfur concentrations would be high because it is well known that Can coals contain high sulfur contents (Sanliyuksel Yucel and Baba 2013a).

\section{Conclusions}

Surface mining for lignite resulted in new artificial lakes. Acid mine lakes are the most important part of the post mining landscape and have ecological as well as socioeconomic functions. The major concern with respect to water quality is whether acidification resulting from mining has been managed successfully. With an increasing demand for efficient environmental monitoring of mining and acid mine lakes, quantitative water monitoring and integration of these data to satellite images and GIS tolls is systematic way for determining border changes of AMLs. This is the first study about change detection and visualization of acid mine lakes using time series satellite image data in geographic information systems in Canakkale province, Turkey. Satellite imagery is providing view of different years' information on a regional scale on land and changes on water bodies.

The environmental problems are the result of 30 years of mining activity and other pollution sources. The AML 2 
and 3 in the Can County will be filled in about 26 years. AMLs cause potential risk of infiltrating the drinking water resources of the surrounding villages. The results show that the number of acid mine lakes increased and these caused environmental risks due to their hydrochemical properties and areal increments. Therefore, a long-term strategy for common water resources management of groundwater and surface water regarding water quantity and quality is necessary. Future work should focus on the determination of AMD treatment alternatives.

Acknowledgments This research is funded by the Canakkale Onsekiz Mart University, Scientific Research Project Number: 2011/082. The authors would like to thank Reviewers for constructive reviews of the manuscript.

\section{References}

Akcil A, Koldas S (2006) Acid mine drainage (AMD): causes, treatment and case studies. J Clean Prod 14:1139-1145

Anderson MC, Norman JM, Mecikalski JR, Torn RD, Kustas WP, Basara JB (2004) A multi-scale remote sensing model for disaggregating regional fluxes to micrometeorological scales. J Hydrometeor 5:343-363

Baba A, Gunduz O (2010) Effect of alteration zones on water quality: a case study from Biga Peninsula, Turkey. Arch Environ Contam Toxicol 58(3):499-513

Baba A, Save D, Gunduz O, Gurdal G, Bozcu M, Sulun S, Ozcan H, Hayran O, Ikiisik H, Bakirci L (2009) The assessment of the mining activities in Can Coal Basin from a medical geology perspective. Final report, The Scientific and Technological Research Council of Turkey (TUBITAK), Project No: CAYDAG-106Y041, Ankara (in Turkish)

Bell FG, Bullock SET, Halbich TFJ, Lindsay P (2001) Environmental impacts associated with an abandoned mine in the Witbank Coalfire, South Africa. Int J Coal Geol 45:195-216

Bhattacharya A, Routh J, Jacks G, Bhattacharya P, Morth M (2006) Environmental assessment of abandoned mine tailings in Adak, Vasterbotten district (northern Sweden). Appl Geochem 21:1760-1780

Bigham JM, Nordstrom DK (2000) Iron and aluminum hydroxysulfates from acid sulfate water. In: Alpers $\mathrm{CN}$, Jambor JL, Nordstrom DK (eds) Review in mineralogy and geochemistry : sulfate minerals: crystallography, geochemistry, and environmental significance, 40th edn. The Mineralogical Society of America, Washington, pp 351-403

Bigham JM, Carlson L, Murad E (1994) Schwertmannite, a new iron oxyhydroxysulfate from Pyhäsalmi, Finland, and other localities. Mineral Mag 58:641-648

Bozcu M, Akgun F, Gurdal G, Yesilyurt SK, Karaca O (2008) Sedimentologic, petrologic, geochemical and palinologic examination of Can Yenice Bayramic (Canakkale) lignite basin. Final Report of the Scientific and Technological Research Council of Turkey (TUBITAK), Project No: CAYDAG-105Y114, Ankara (in Turkish)

Cravotta AC (2008) Dissolved metals and associated constituents in abandoned coal-mine discharges, Pennsylvania, USA. Part 1: constituent quantities and correlations. Appl Geochem 23:166-202

Environmental Protection Agency (2003) National primary drinking water standards. Office of Water, United States Environmental Protection, EPA 816-F-03-016
Equeenuddin SM, Tripathy S, Sahoo PK, Panigrahi MK (2010) Hydrogeochemical characteristics of acid mine drainage and water pollution at Makum Coalfield, India. J Geochem Explor 105:75-82

Ercan T, Satir M, Steinitz G, Dora A, Sarifakioglu E, Adis C, Walter HJ, Yildirim T (1995) Characteristics of the tertiary volcanism in the Biga Peninsula, Gokceada, Bozcaada and Tavsanadasi, NW Anatolia. MTA Bull 117:55-86 (in Turkish)

Gurdal G (2011) Abundances and modes of occurrence of trace elements in the Can coals (Miocene), Canakkale-Turkey. Int J Coal Geol 87:157-173

ITASHY (2005) Regulation on waters intended for human consumption. Official Gazette dated 17/02/2005, No:25730, Ankara (in Turkish)

Latifovic R, Fytas K, Chen J, Paraszczak J (2005) Assessing land cover change resulting from large surface mining development. Int J Appl Earth Obs 7:29-48

Latifovic R, Fytas K, Paraszczak J (2006) Satellite remote sensing as means to assess primary impact of open-pit mining. In: New technological solutions in underground mining: International Mining Forum 2006. Proceedings and monographs in engineering, water and earth sciences, Cracow, Poland, pp 161-171

Lee JS, Chon HT (2006) Hydrogeochemical characteristics of acid mine drainage in the vicinity of an abandoned mine, Daduk Creek, Korea. J Geochem Explor 88:37-40

Lee G, Bigham JM, Faure G (2002) Removal of trace metals by coprecipitation with $\mathrm{Fe}, \mathrm{Al}$ and $\mathrm{Mn}$ from natural waters contaminated with acid mine drainage in the Ducktown Mining District, Tennessee. Appl Geochem 17:569-581

Mapper (TM) (2010). http://eros.usgs.gov/\#/Find_Data/Products_ and Data_Available/TM

Mills C (1995) An AMD/ARD dedicated blog, based on the text of a presentation given Mills to British Columbia high school science teachers. In: A seminar on acid rock drainage at the cordilleran roundup, Vancouver

Monterroso C, Macias F (1998) Drainage waters affected by pyrite oxidation in a coal mine in Galicia, NW Spain: composition and mineral stability. Sci Total Environ 216:121-132

Nordstrom DK (1982) Aqueous pyrite oxidation and the consequent formation of secondary iron minerals. In: Kittrick JA, Fanning DS, Hossner LR (eds) Acid sulfate weathering. Soil Science Society of America Special Publication 10, Madison, pp 37-55

Nordstrom DK, Alpers CN, Ptacek CJ, Blowes DW (2000) Nagative $\mathrm{pH}$ and extremely acidic mine waters from Iron Mountain, California. Environ Sci Technol 34:254-258

Oh HJ, Lee S (2011) Integration of ground subsidence hazard maps of abandoned coal mines in Samcheok, Korea. Int J Coal Geol 86:58-72

Ozcelik GA (2007) Prediction techniques of acid mine drainage: A case study of a new poly- metallic mine development in Erzincan-Ilic, Turkey. PhD Thesis, The Graduate School of Natural and Applied Sciences of Middle East Technical University, pp 260

Ozesmi S, Bauer M (2002) Satellite remote sensing of wetlands. Wetlands Ecol Manag 10:381-402

Paktunc AD (1999) Characterization of mine wastes for prediction of acid mine drainage. In: Azcue JM (ed) Environmental impacts of mining activities. Springer, Berlin, pp 19-39

Paterson N (1997) Remote mapping of mine wastes. In: Gubins AG (ed.) Mapping and monitoring the mine environment. In: Proceedings of exploration 97: fourth decennial international conference on mineral exploration, pp 905-916

Peichang S, Cheng S, Smith S (2004) Acid lake identification using GIS and remote sensing. In: Geological Society of America, Denver annual meeting, November 7-10

Ribeiro J, Ferreira da Silva E, Li Z, Ward C, Flores D (2010) Petrographic, mineralogical and geochemical characterization of 
the Serrinha coal waste pile (Douro Coalfield, Portugal) and the potencial environmental impacts on soil, sediments and sufarce waters. Int J Coal Geol 83:456-466

Robitaille R, Dempsey D, Galli A (1991) The use of landsat TM imagery in the detection of mine sites and mine wastes in the Sudbury, Ontario region. In: Proceedings eight thematic conference on geologic remote sensing, pp 955-958

Sabins FF (1999) Remote sensing for mineral exploration. Ore Geol Rev 14:157-183

Sanliyuksel D, Baba A (2011) Effects of the abandoned mining wastes on water resources in Can Basin. In: 64th geological congress of Turkey, Ankara, pp 47-48

Sanliyuksel Yucel D (2013) Characteristics of acidic water resources, factors enabling their formation and hydrogeochemical properties (Can-Bayramic; Biga Peninsula). Doctoral Dissertation in Geology Engineering, Graduate School of Natural and Applied Sciences, Canakkale Onsekiz Mart University (in Turkish)

Sanliyuksel Yucel D, Baba A (2013a) Geochemical characterization of acid mine lakes and their effect on the environment, NW of Turkey. Arch Environ Contam Toxicol 64:357-376

Sanliyuksel Yucel D, Baba A (2013b) Effects of acid mine lakes on water resources in Biga Peninsula, Turkey. In: The second international conferance on water, energy and the environment (ICWEE'2013). Kusadasi, Turkey, Paper number 277, pp 1-10

Sanliyuksel Yucel D, Sengun F, Baba A (2012) Effects of alteration zones on water resources in Can Basin. In: 65th geological congress of Turkey, Ankara, pp 122-123

Sanliyuksel Yucel D, Baba A, Sengun F, Yücel MA (2013) Drainage waters affected by pyrite oxidation in an open pit coal mine in Can Region, NW Turkey. In: IAH 2013 Congress, Perth, Australia, paper number 32, pp 65

Schroeter L, Glasser C (2011) Analyses and monitoring of lignite mining lakes in Eastern Germany with spectral signatures of Landsat TM satellite data. Int J Coal Geol 86:27-39

Si H, Bi H, Li X, Yang C (2010) Environmental evaluation for sustainable development of coal mining in Qijiang, Western China. Int J Coal Geol 81:163-168

Siyako M, Burkan KA, Okay AI (1989) Tertiary geology and hydrocarbon potential of the Biga and Gelibolu Peninsulas. Turk Petrol Geologists Assoc Bull 1(3):183-200 (in Turkish)

Spahn JL (1983) A land cover classification of a portion of the Western Kentucky coal field utilizing multi-temporal thematic mapper simulator data. In: ACSM-ASP Fall convention proceedings, pp 367-377

SRK (2012) Preliminary economic assessment technical report for the Halilağa Project, Turkey. Report Prepared for Truva Bakır Maden İşletmeleri Inc. and Pilot Gold Inc. Report Prepared by SRK Consulting (Canada) Inc., Ankara. pp 249

Thematic Mapper Plus (ETM+) (2012). http://eros.usgs.gov/\#/Find_ Data/Products_and_Data_Available/ETM

USEPA (1994a) Innovative methods of managing environmental releases at mine sites. US Environmental Protection Agency, Office of Solid Waste, Special Wastes Branch, Washington (OSW Doc. 530-R-94-012, April)

USEPA (1994b) Acid mine drainage prediction. US Environmental Protection Agency, Office of Solid Waste, Special Wastes Branch, Washington (EPA 530-R-94-036, December)

USGS (ed.) (2006a) Landsat Project. http://landsat.usgs.gov

USGS (ed.) (2006b) Earth resources observation and science (EROS). Landsat Enhanced

USGS (ed.) (2006c) Earth resources observation and science (EROS). Landsat Thematic

Woldai T (2001) Applications of remotely sensing data and GIS in assessing the impact of mining activities on the environment, in IMCET. In: Proceedings of the 17th international mining congress and exhibition of Turkey, pp 75-83

WHO (2004) World health organization guidelines for drinking water quality, vol 1, 3rd edn. WHO, Geneva

Yenilmez F, Kuter N, Emil MK, Aksoy A (2011) Evaluation of pollution levels at an abandoned coal mine site in Turkey with the aid of GIS. Int J Coal Geol 86:12-19

Yucel MA, Sanliyuksel Yucel D (2012) Determining and visualization of border changing on coal mining activities with satellite images and geographic information system (GIS) in Can (Canakkale) County, Canakkale Onsekiz Mart University Scientific Research Project, Project Number: BAP 2011/082, pp 40 (in Turkish)

Yucel MA, Sanlyyuksel Yucel D, Baba A (2013) Determining and monitoring of acid mine lakes using satellite images and geographic information system (GIS) in Can County, NW Turkey. In: IAH 2013 Congress, Perth, Australia, Paper number 106, pp 195 